\title{
Acute and chronic effects of clomipramine on isolation-induced aggression in male mice
}

\author{
J. J. BORRÁS-VALLS, A. SALVADOR, and V. M. SIMÓN \\ Universitat de València, Valencia, Spain
}

\begin{abstract}
The behavioral effects of clomipramine were studied on an ethopharmacological model of aggression. A range of low doses (similar to those used in clinical practice: $1.5,3$, and $6 \mathrm{mg} / \mathrm{kg}$ ) and a higher dose (24 mg/kg - more usual in animal experimentation) were administered to isolated male mice that confronted anosmic opponents in a neutral arena. Encounters were staged $30 \mathrm{~min}$ after acute treatment and either $30 \mathrm{~min}$ or $24 \mathrm{~h}$ after the last drug administration in the chronic (21-day) treatment. Significant behavioral effects were observed predominantly with the highest dose. Acute and chronic effects were similar in the sense that both decreased aggressive behavior and produced some impairment of motor behavior, but differed in that such antiaggressive action was more potent in the chronic treatment, whereas the motility impairment was stronger in the acute one. The two chronic evaluations (at $30 \mathrm{~min}$ or $24 \mathrm{~h}$ ) did not produce widely different results.
\end{abstract}

Although the therapeutic effects of antidepressant drugs only appear after 2 or 3 weeks of treatment, few animal studies have employed chronic administration of tricyclic compounds. Vogel, Minter, and Woolwine (1986) found only 14 papers reporting behavioral effects of chronically administered antidepressants. Furthermore, even in the scarce existing literature the results do not always agree; both increases and decreases in aggressive behavior have been reported (Willner, Theodorou, \& Montgomery, 1981). This is also the case with clomipramine, a tricyclic antidepressant that has also proved to be effective in the treatment of obsessive-compulsive and panic disorders (McTavish \& Benfield, 1990). The most important metabolic routes of clomipramine are demethylation to demethylclomipramine and hydroxylation to hydroxy-clomipramine (Gex-Fabry, Balant-Gorgia, Balant, \& Garrone, 1990). Clomipramine (a potent serotonin reuptake inhibitor) and demethylclomipramine (a potent norepinephrine reuptake inhibitor) are considered to be pharmacologically active (Balant-Gorgia, Gex-Fabry, \& Balant, 1991), although 8-hydroxylated metabolites could also exert pharmacological effects (Linnoila, Insel, Kilts, Potter, \& Murphy, 1982).

Delini-Stula and Vassout (1981) studied the effects of the daily administration of clomipramine $(10 \mathrm{mg} / \mathrm{kg})$ on isolated male mice for a period of over 21 days. Aggressiveness was tested frequently (every 2 or 3 days) and latency to the first attack was measured. A progressive decrease of aggressiveness was evident over treatment. The drug began to take effect on Day 3 , but clear-cut effects were observed by Weeks 2 and 3 . In other studies

Address correspondence to V. M. Simón, Area de Psicobiología, Facultad de Psicología, Universitat de València, Apartado 22109, 46071 Valencia, Spain. of the chronic effects of clomipramine, with different experimental paradigms, contradictory results have been found (Maj, Mogilnicka, \& Kordecka, 1979; Valdman \& Poshivalov, 1986; Vogel, Hartley, Neill, Hagler, \& Kors, 1988). The techniques used to elicit aggression in these studies are disparate from that used in the isolation paradigm.

Research on the acute effects of clomipramine on aggressive behavior has generally shown that this drug suppresses muricide in rats (Shibata, Nakanishi, Watanabe, \& Ueki, 1984; Yamamoto \& Ueki, 1978). Nevertheless, Schmidt and Meierl (1980), using male ferrets as experimental animals and rats as prey, found that clomipramine $(15 \mathrm{mg} / \mathrm{kg})$ did not inhibit capturing and that the number of bites after the death of the prey increased significantly.

When isolation-induced aggression models have been employed, the predominantly described effect of acute clomipramine has also been moderately antiaggressive. Delini-Stula and Vassout (1979) studied the effects of acute clomipramine (10 and $25 \mathrm{mg} / \mathrm{kg}$ ) on isolation-induced (4-8 weeks) aggression in male mice and found that a dose of $25 \mathrm{mg} / \mathrm{kg}$ increased latency to the first attack, but was ineffective in suppressing this type of aggression. Krsiak et al. (1981), using albino male mice that had been 3-6 weeks in isolation and group-housed mice as opponents, found that clomipramine (10 and $20 \mathrm{mg} / \mathrm{kg}$ ), given $60 \mathrm{~min}$ before agonistic interactions, reduced attacks. When other antidepressant drugs were studied, some produced similar results and some produced contradictory converse findings (for reviews, see Miczek, 1987; Vogel et al., 1986).

The purpose of the present study was to assess the chronic effects of clomipramine and to detect possible differences between its acute and chronic actions. Furthermore, we explored the possibility that, in chronic 
Table 1

Median Values and Ranges for Times (in Seconds) Allocated to Broad Behavioral Categories in Animals Receiving Acute Treatment With Clomipramine With an Interval Injection Test of $\mathbf{3 0}$ min

\begin{tabular}{|c|c|c|c|c|c|c|c|c|c|c|}
\hline \multirow[b]{3}{*}{$\begin{array}{l}\text { Behavioral } \\
\text { Categories }\end{array}$} & \multirow{2}{*}{\multicolumn{2}{|c|}{ Saline }} & \multicolumn{8}{|c|}{ Doses of Clomipramine } \\
\hline & & & \multicolumn{2}{|c|}{$1.5 \mathrm{mg} / \mathrm{kg}$} & \multicolumn{2}{|c|}{$3 \mathrm{mg} / \mathrm{kg}$} & \multicolumn{2}{|c|}{$6 \mathrm{mg} / \mathrm{kg}$} & \multicolumn{2}{|c|}{$24 \mathrm{mg} / \mathrm{kg}$} \\
\hline & $\begin{array}{c}\text { Median } \\
\text { Value }\end{array}$ & Range & $\begin{array}{c}\text { Median } \\
\text { Value }\end{array}$ & Range & $\begin{array}{c}\text { Median } \\
\text { Value }\end{array}$ & Range & $\begin{array}{c}\text { Median } \\
\text { Value }\end{array}$ & Range & $\begin{array}{l}\text { Median } \\
\text { Value }\end{array}$ & Range \\
\hline Body care & 8.3 & $3.2-25$ & 10.6 & $1-35.6$ & 7.7 & $3.4-22$ & 8.7 & $3.7-14.3$ & 0 & $0-12$ \\
\hline Digging & 3.4 & $0-26$ & 7.4 & $0-24.4$ & 0.8 & $0-21.2$ & 2.4 & $0-18$ & 0 & $0-1.1$ \\
\hline $\begin{array}{l}\text { Nonsocial } \\
\text { exploration }\end{array}$ & 404 & $310.6-437.5$ & 415.2 & $335.2-471.1$ & 375.1 & $301.7-459.6$ & 408.6 & $357.6-498.1$ & 424.8 & $54-475.6$ \\
\hline $\begin{array}{l}\text { Exploration from } \\
\text { a distance }\end{array}$ & 36.2 & $26.8-60.9$ & 35 & $28.4-60.4$ & 35.8 & $20.4-76.9$ & 39.4 & $9.7-61.3$ & $63.6^{*}$ & $29.5-137.1$ \\
\hline $\begin{array}{l}\text { Social } \\
\text { investigation }\end{array}$ & 43.1 & $0.8-162.7$ & 35.7 & $3.9-128.6$ & 45.9 & $18.8-148.8$ & 61.7 & $15.8-204.3$ & 41.4 & $20.2-69.1$ \\
\hline Threat & 78.4 & $6.2-120.3$ & $52.4^{*}$ & $0-108.2$ & 86.9 & $0-145.6$ & $39^{*}$ & $0-106.6$ & $0^{*}$ & $0-45.5$ \\
\hline Attack & 17.7 & $0-59.9$ & 7.4 & $0-25.7$ & 11.5 & $0-58.8$ & 3.5 & $0-69.6$ & 0 & $0-10.1$ \\
\hline Avoidance/fleeing & 0.1 & $0-2.8$ & 0.7 & $0-6.1$ & 0.6 & $0-14$ & 0.3 & $0-9.4$ & $26.1^{*}$ & $2.5-57.9$ \\
\hline $\begin{array}{l}\text { Defensive/ } \\
\text { submissive }\end{array}$ & 0 & $0-0.8$ & 0 & $0-3.3$ & 0 & $0-2.6$ & 0 & $0-0.6$ & 2.0 & $0-69.7$ \\
\hline Immobility & 0 & $0-2.3$ & 0 & $0-56.5$ & 0.2 & $0-5.6$ & 0.3 & $0-3.1$ & $4.5^{*}$ & 080.5 \\
\hline
\end{tabular}

Note-Kruskal-Wallis test showed significant variance $(p<.05)$ for defensive/submissive. Kruskal-Wallis test showed significant variance $(p<$ $.01)$ for body care, digging, exploration from a distance, threat, attack, avoidance/fleeing, and immobility. ${ }^{*}$ Differs from controls $(p<.01)$ on Dunn-Bonferroni test.

treatment, the time elapsed since the last injection may be of importance (Vogel et al., 1986), performing behavioral tests either $30 \mathrm{~min}$ or $24 \mathrm{~h}$ after the last injection. The rationale behind this procedure was that after $24 \mathrm{~h}$, the acute effects would have worn off, whereas chronic effects would still be present. A range of low doses $(1.5,3$, and $6 \mathrm{mg} / \mathrm{kg})$ close to those customary in clinical practice was explored, plus a higher dose of $24 \mathrm{mg} / \mathrm{kg}$, which lies in the dose range normally employed in animal experimentation. An isolation-induced aggression paradigm with a detailed ethopharmacological technique of behavioral assessment was used.

\section{METHOD}

\section{Subjects}

All animals were male albino mice of the OF1 strain, acquired commercially from Laboratories IFFA CREDO (France) at 42 days of age. They were maintained on a reversed light:dark schedule (lights on $2130-0930 \mathrm{~h}$, local time). Food and water were supplied ad lib, and the temperature was regulated between $18^{\circ}$ and $21^{\circ} \mathrm{C}$. Upon arrival in the laboratory, the subjects were allocated to two different categories. The experimental subjects were individually housed in transparent plastic cages measuring $24 \times$ $13.5 \times 13 \mathrm{~cm}$. The "standard opponents" remained in groups of 10 , housed in plastic cages measuring $24 \times 13.5 \times 24 \mathrm{~cm}$ and were made anosmic by intranasal lavage with a $4 \%$ zinc sulphate solution 1 day before testing. This kind of opponent (used once only) was employed because it elicits attack, but never initiates such behavior (Brain, Benton, Childs, \& Parmigiani, 1981). All the experimental animals underwent an isolation period of 49 days before the behavioral test.

\section{Drug}

Clomipramine (Anafranil; Geigy, Spain) was diluted in physiological saline to provide appropriate doses for injection. It was administered either acute or chronically in four doses: $1.5,3,6$, and
$24 \mathrm{mg} / \mathrm{kg}$. Control groups received physiological saline. Drug or vehicle was injected intraperitoneally (i.p.) in a volume of $5 \mathrm{ml} / \mathrm{kg}$.

\section{Procedure}

One hundred eighty individually housed male mice were used. They were divided into groups of 12; each group received different doses of clomipramine (or physiological saline) in one of the following treatments. (1) Acute treatment: a single dose was administered $30 \mathrm{~min}$ before testing (interval injection test, $30 \mathrm{~min}$ ). (2) Chronic treatment (interval injection test, $30 \mathrm{~min}$ ): each animal received a daily injection for 21 consecutive days. The social encounters took place $30 \mathrm{~min}$ after the last injection. (3) Chronic treatment (interval injection test, $24 \mathrm{~h}$ ): each animal received a daily injection for 21 consecutive days. The social encounters took place $24 \mathrm{~h}$ after the last injection. The body weights of the animals that were chronically treated with clomipramine were taken daily during the period of treatment.

\section{Social Encounter Test}

After undergoing particular treatments, an experimental animal and a "standard opponent" were paired in a neutral arena. This neutral cage consisted of an all-glass area, measuring $60 \times 33 \times$ $30 \mathrm{~cm}$, with a fresh sawdust substrate. While separated by means of a plastic barrier, the animals were allowed $1 \mathrm{~min}$ of adaptation to the neutral cage before the encounter. The social encounters lasted $10 \mathrm{~min}$ and were videotaped using a Panasonic NV camera, a Panasonic NV-770 video, and a Sony Trinitron monitor. All the tests were carried out under white lighting between the second and fifth hours of the dark phase of the artificial cycle of the animals.

\section{Behavioral Analysis}

Behavior was assessed using an ethological technique based on a computer program (Brain, McAllister, \& Walmsley, 1989). This program allows the use of a microprocessor to compute the frequency and duration of 11 broad behavioral categories: body care, digging, nonsocial exploration, exploration from a distance, social investigation, threat, attack, avoidance/fleeing, defensive/submissive, immobility, and sexual activities. Each category represents a group of different elements and postures. A detailed description of 
Table 2

Median Values and Ranges for Times (in Seconds) Allocated to Broad Behavioral Categories in Animals Receiving Chronic Treatment With Clomipramine With an Interval InjectionTest of 30 min

\begin{tabular}{|c|c|c|c|c|c|c|c|c|c|c|}
\hline \multirow[b]{3}{*}{$\begin{array}{l}\text { Behavioral } \\
\text { Categories }\end{array}$} & \multirow{2}{*}{\multicolumn{2}{|c|}{ Saline }} & \multicolumn{8}{|c|}{ Doses of Clomipramine } \\
\hline & & & \multicolumn{2}{|c|}{$1.5 \mathrm{mg} / \mathrm{kg}$} & \multicolumn{2}{|c|}{$3 \mathrm{mg} / \mathrm{kg}$} & \multicolumn{2}{|c|}{$6 \mathrm{mg} / \mathrm{kg}$} & \multicolumn{2}{|c|}{$24 \mathrm{mg} / \mathrm{kg}$} \\
\hline & $\begin{array}{l}\text { Median } \\
\text { Value }\end{array}$ & Range & $\begin{array}{c}\text { Median } \\
\text { Value }\end{array}$ & Range & $\begin{array}{l}\text { Median } \\
\text { Value }\end{array}$ & Range & $\begin{array}{l}\text { Median } \\
\text { Value }\end{array}$ & Range & $\begin{array}{c}\text { Median } \\
\text { Value }\end{array}$ & Range \\
\hline Body care & 8.5 & $3.2-28.7$ & 9.1 & $1.5-33.5$ & 14.1 & $4.9-46.3$ & 8.7 & $2.4-23.2$ & 0.9 & $0-6.9$ \\
\hline Digging & 3.7 & $0-20.2$ & 0.4 & $0-13.6$ & 3.1 & $0-27.9$ & 3.1 & $0-11.9$ & 0 & $0-2.7$ \\
\hline $\begin{array}{l}\text { Nonsocial } \\
\text { exploration }\end{array}$ & 66.5 & $163.5-434.3$ & 344.9 & $273.4-498.2$ & 351.2 & $273.5-488$ & 399.4 & $182.3-474.9$ & 360.7 & $242.2-477.5$ \\
\hline $\begin{array}{l}\text { Exploration from } \\
\text { a distance }\end{array}$ & 20.8 & $8.4-74.7$ & 22.7 & $16.6-50.7$ & 22.3 & $10.2-42.7$ & 19.5 & $9.2-58.9$ & $65.6^{*}$ & $25.4-107.2$ \\
\hline $\begin{array}{l}\text { Social } \\
\quad \text { investigation }\end{array}$ & 95.9 & $7.5-308.2$ & 102 & $22.1-245.9$ & 77.9 & $13-181.7$ & 126 & $21.4-191.8$ & 96.3 & $35.8-211$ \\
\hline Threat & 62.8 & $12.9-213.9$ & 75 & $0-151$ & 58.3 & $0.3-268.5$ & 40.8 & $0-229.4$ & 6.4 & $0-159.3$ \\
\hline Attack & 29.8 & $0-127.4$ & 12.1 & $0-113.3$ & 10.8 & $0-84.8$ & $8.4^{*}$ & $0-34.6$ & $0^{*}$ & $0-21.5$ \\
\hline Avoidance/fleeing & 0 & $0-1.8$ & 0.7 & $0-1.5$ & 0.6 & $0-17.7$ & 0.4 & $0-2.7$ & 12.4 & $0.9-53.5$ \\
\hline $\begin{array}{l}\text { Defensive/ } \\
\text { submissive }\end{array}$ & 0 & $0-2.3$ & 0 & $0-0$ & 0 & $0-0.6$ & 0 & $0-9.5$ & 2.9 & $0-25.8$ \\
\hline Immobility & 0.1 & $0-24.8$ & 0.1 & $0-2$ & 0.2 & $0-2.1$ & 0.1 & $0-2.3$ & 0 & $0-0.4$ \\
\hline
\end{tabular}

Note-Kruskal-Wallis test showed significant variance $(p<.01)$ for body care, exploration from a distance, attack, avoidance/fleeing, and defensive/submissive. *Differs from controls $(p<.01)$ on Dunn-Bonferroni test.

these categories and postures can be found in Martínez, Castaño, Simón, and Brain (1986) and Brain et al. (1989).

The analysis of the videotapes involved assessment only of the behavior of the experimental animals. This analysis was performed by a trained experimenter who was blind as to the experimental group to which each animal belonged. No sexual behavior was recorded in these experiments, so this category does not appear in the results.

\section{Statistical Analysis \\ Nonparametric Kruskal-Wallis tests used as the criteria for parametric statistics (ANOVA) were not met. Subsequently, ap- propriate paired comparisons were carried out using the Dunn- Bonferroni test, since multiple comparisons were made (San Mar- tin \& Pardo, 1989). \\ In the other comparison (between controls of acute and chronic treat- ments), Mann-Whitney $U$ tests were used.}

\section{RESULTS}

\section{Acute Treatment}

The data for this test is given in Table 1. The KruskalWallis analysis showed a significant effect of clomipramine on several behavioral categories (body care, digging, exploration from a distance, threat, attack, avoidance/fleeing, defensive/submissive, and immobility). But post hoc comparisons were only significant on four categories, especially with the highest dose. Low doses of clomipramine $(1.5$ and $6 \mathrm{mg} / \mathrm{kg}$ ) only significantly reduced threat $(p<.01)$. However, the highest dose $(24 \mathrm{mg} / \mathrm{kg})$ significantly reduced threat and increased exploration from a distance, avoidance/fleeing, and immobility.

\section{Chronic Treatment}

The medians and ranges of the total duration of all behavioral categories relative to daily treatment of clomipramine with an interval injection test of $30 \mathrm{~min}$ are given in Table 2 . The Kruskal-Wallis test showed sig- nificant variance for body care, exploration from a distance, attack, avoidance/fleeing, and defensive/submissive. Attack diminished, but only significantly $(p<.01)$ with the $6-\mathrm{mg} / \mathrm{kg}$ and $24-\mathrm{mg} / \mathrm{kg}$ doses. The highest dose also increased exploration from a distance $(p<.01)$.

In daily treatment with an interval injection test of $24 \mathrm{~h}$ (see Table 3), the Kruskal-Wallis analysis showed significant variance for digging, exploration from a distance, attack, avoidance/fleeing, and immobility. Post hoc comparisons between treated and control groups showed only significant differences in two behavioral categories with the highest dose-a decrease in attack and an increase in exploration from a distance.

No significant differences were found between the body weights of treated and control animals, so these data are not presented.

No significant differences were found (Mann-Whitney $U$ test) from a comparison between control groups of the acute and chronic treatments with an interval injection test of $30 \mathrm{~min}$.

\section{DISCUSSION}

Miczek (1987) reported that the effects of chronic treatment with antidepressants are often opposite to those of acute treatments. In contrast, our results show a similar pattern of changes after both types of administration. This pattern consists of a reduction in offensive behavior and an increase in exploration from a distance, which can be interpreted as timid behavior.

At doses clinically effective in humans $(1.5,3$, and $6 \mathrm{mg} / \mathrm{kg}$ ), acute treatment with clomipramine was not effective in producing behavioral changes in this animal model of aggression (except for a reduction in threat behavior). Only the highest dose $(24 \mathrm{mg} / \mathrm{kg})$ generated important effects on several behaviors. These results sup- 
Table 3

Median Values and Ranges for Times (in Seconds) Allocated to Broad Behavioral Categories in Animals Receiving Chronic Treatment With Clomipramine With an Interval Injection Test of $24 \mathrm{~h}$

\begin{tabular}{|c|c|c|c|c|c|c|c|c|c|c|}
\hline \multirow[b]{3}{*}{$\begin{array}{l}\text { Behavioral } \\
\text { Categories }\end{array}$} & \multicolumn{10}{|c|}{ Doses of Clomipramine } \\
\hline & \multicolumn{2}{|c|}{ Saline } & \multicolumn{2}{|c|}{$1.5 \mathrm{mg} / \mathrm{kg}$} & \multicolumn{2}{|c|}{$3 \mathrm{mg} / \mathrm{kg}$} & \multicolumn{2}{|c|}{$6 \mathrm{mg} / \mathrm{kg}$} & \multicolumn{2}{|c|}{$24 \mathrm{mg} / \mathrm{kg}$} \\
\hline & $\begin{array}{c}\text { Median } \\
\text { Value }\end{array}$ & Range & $\begin{array}{c}\text { Median } \\
\text { Value }\end{array}$ & Range & $\begin{array}{c}\text { Median } \\
\text { Value }\end{array}$ & Range & $\begin{array}{c}\text { Median } \\
\text { Value }\end{array}$ & Range & $\begin{array}{c}\text { Median } \\
\text { Value }\end{array}$ & Range \\
\hline Body care & 10.5 & $1.2-27.8$ & 13.1 & $2.7-18.1$ & 8.9 & $3.5-36.4$ & 12 & $5.1-23.5$ & 6 & $0-56.7$ \\
\hline Digging & 4.1 & $0-14.4$ & 5.4 & $0-28.8$ & 9.5 & $0-50.2$ & 7.9 & $0-45.9$ & 0.2 & $0-8.3$ \\
\hline $\begin{array}{l}\text { Nonsocial } \\
\text { exploration }\end{array}$ & 348.3 & $303-419.4$ & 354.2 & $264.3-413$ & 354.7 & $293.8-452.1$ & 359.3 & $222.6-414.5$ & 346.1 & $222.7-438.3$ \\
\hline $\begin{array}{l}\text { Exploration from } \\
\text { a distance }\end{array}$ & 23.2 & $13.4-54.4$ & 28.7 & $17.7-53.6$ & 26.6 & $13.2-75$ & 28.5 & $16.1-41.9$ & $53^{*}$ & $7.7-148.1$ \\
\hline $\begin{array}{l}\text { Social } \\
\quad \text { investigation }\end{array}$ & 114.7 & $32-170.5$ & 84.5 & $22-214.7$ & 114.6 & $34.6-192.8$ & 119.2 & $61.4-339.2$ & 136 & $25.8-258.6$ \\
\hline Threat & 47.8 & $10-114.8$ & 51.5 & $24.6-156.7$ & 36.4 & $0-90.2$ & 39.8 & $0.5-96.9$ & 44.1 & $0-133$ \\
\hline Attack & 29.6 & $0-101.6$ & 31.2 & $15.7-93.2$ & 11.1 & $0-98.4$ & 16 & $0-45.5$ & $6.0^{*}$ & $0-83.6$ \\
\hline Avoidance/fleeing & 0.6 & $0-2.3$ & 0.5 & $0-7.3$ & 0.4 & $0-8.6$ & 0 & $0-1.7$ & 1.6 & $0-31.5$ \\
\hline $\begin{array}{l}\text { Defensive/ } \\
\text { submissive }\end{array}$ & 0 & $0-0$ & 0 & $0-0$ & 0 & $0-3.2$ & 0 & $0-3.1$ & 0 & $0-17.7$ \\
\hline Immobility & 0 & $0-0.7$ & 0.5 & $0-3.8$ & 0.1 & $0-1.3$ & 0 & $0-6.1$ & 0.4 & $0-42.2$ \\
\hline
\end{tabular}

Note-Kruskal-Wallis test showed significant variance $(p<.05)$ for digging and avoidance/fleeing. Kruskal-Wallis test showed significant variance $(p<.02)$ for exploration from a distance, attack, and immobility. *Differs from controls $(p<.01)$ on Dunn-Bonferroni test.

port previous findings obtained with relatively high doses of other antidepressants, in which decreases of aggressive and motor behaviors were found (Boissier, Grasset, \& Simon, 1968; Delini-Stula \& Vassout, 1979; Krsiak, 1976, 1979; LeDouarec \& Broussy, 1969; Sofia, 1969; Valzelli \& Bernasconi, 1971; Valzelli, Giacalone, \& Garattini, 1967). There is considerable evidence that points to the neurotransmitter serotonin as a potent inhibitor of aggression in animals as well as human beings (Eichelman, 1987; Sheard, 1988). Olivier, Mos, Van der Heyden, and Hartog (1989) have described a reduction in attack behavior with different serotonergic agonists (e.g., eltoprazine) and selective uptake blockers (e.g., fluvoxamine). Increases in offensive behavior have been found after serotonin reductions by PCPA in rats (Vergnes, Depaulis, \& Boehrer, 1986) and mice (Gianutsos \& Lal, 1975). The reduction of offensive behavior found in our experiment, in which tests were carried out $30 \mathrm{~min}$ after the acute administration of clomipramine, is compatible with a serotonergic effect of the drug, since at this time the plasma levels of clomipramine (which is more serotonergic) will be higher than those of its active metabolite, demethylclomipramine, which is more noradrenergic (BalantGorgia et al., 1991).

This reduction in offensive behaviors seems to be accompanied by significant increases of timid behaviors (such as avoidance/flee and exploration from a distance), which are in agreement with the results of Krsiak et al. (1981). Such increases of timid behaviors pose the question of the influence of clomipramine on anxiety. Some researchers (Benton, Smoothy, \& Brain, 1985; Krsiak \& Sulcova, 1990; Redolat, Miñarro, Simón, \& Brain, 1991; Smoothy, Brain, Berry, \& Haug, 1986) have interpreted the appearance of timid/defensive be- haviors in this experimental paradigm as manifestations of anxiety. In this regard, the results presented in this paper suggest that increases in serotonergic activity would elevate anxiety levels, a conclusion that, although compatible with the findings reported in animal research (Iversen, 1984), is not supported by the effectiveness that serotonin reuptake inhibitors show in the treatment of panic disorders in humans (Eriksson, 1987).

It is interesting to note that the impairment of motor behavior, as measured by the increase found in immobility, was small. Immobility was significantly increased by the highest dose, but only to reach a median of $4.5 \mathrm{sec}$. Some motor behaviors, such as nonsocial exploration (which represents about $60 \%$ of the total time) and social investigation, were not affected, but others (e.g., avoidance/fleeing) clearly increased. The significant decrease found in threat behavior and the nonsignificant reductions observed in attack and displacement behaviors (body care and digging) do not seem to be easily explained in terms of mobility impairment. In general, surprisingly few studies have explored the effects of clomipramine on mobility (Wittenborn, 1978), and the current data only point to a moderate impairment of motor behavior (Kjellberg \& Randrup, 1975; Tiller, 1990).

Contrary to the acute treatment, in chronically treated animals tested 30 min after the last injection, immobility was not significantly increased. This difference may be explained by development of tolerance or by secondary effects (manipulation, daily injection) of the chronic treatment. To exclude this latter possibility, the control groups of the acute and chronic treatments were compared, and no significant differences were found. Therefore, tolerance seems to be the most likely explanation for the absence of clear motor impairment in this 
treatment condition. With respect to aggressive behavior, clomipramine has shown a more potent antiaggressive action in chronic than in acute treatment. A significant reduction of attack behavior was found not only with the $24-\mathrm{mg} / \mathrm{kg}$ dose but also with the $6-\mathrm{mg} / \mathrm{kg}$ dose, clearly showing that there was no tolerance to the antiaggressive effects of clomipramine in the chronically treated animals. When the control groups of the acute and chronic treatments were compared, no differences in aggressive behavior were found. Therefore, there was no evidence that the daily handling of the animals had any important effect on attack behavior, as has been found by other authors (Goldberg, 1970; Willner et al., 1981). The reductions in offensive behaviors observed in the present experiment are in agreement with the decreases in aggression reported by Delini-Stula and Vassout (1981) after a 21 -day treatment with $10 \mathrm{mg} / \mathrm{kg}$ clomipramine, using latency of first attack as a behavioral measure. On the other hand, a similar divergence between antiaggressive and motor effects in the chronic treatment has also been described after repeated administration of neuroleptics, such as haloperidol (Navarro, Miñarro, \& Simón, 1993).

The pattern of behavioral changes at $24 \mathrm{~h}$ is similar to the one found at $30 \mathrm{~min}$. The differences found between both chronic treatments ( $30 \mathrm{~min}$ and $24 \mathrm{~h}$ ) were minimal, so they do not pose any difficulty for the interpretation that the effects found at $24 \mathrm{~h}$ are a result of those found at $30 \mathrm{~min}$. This is of importance when considering the possibility that the acute effects are qualitatively different from the chronic ones (which would support the idea that the long-term effects produced by changes in receptor sensitivity are supposedly related to the therapeutic actions in depressive patients). From the results of the present experiment, such an interpretation is not warranted.

In conclusion, in this experiment the effects of both acute and chronic treatment with clomipramine were in the same direction - the reduction of aggressive behavior. Furthermore, the antiaggressive action observed in the chronic treatment was slightly, but significantly, superior than the action observed in the acute treatment. On the other hand, the depressant action on mobility found in the acutely treated group had disappeared in the chronic condition. Almost all behavioral effects found in this ethopharmacological model of isolation-induced aggression have been seen with doses clearly much higher than those used in human clinical application $(24 \mathrm{mg} / \mathrm{kg})$.

\section{REFERENCES}

Balant-Gorgia, A. E., Gex-Fabry, M., \& Balant, L. (1991). Clini$\mathrm{cal}$ pharmacokinetics of clomipramine. Clinical Pharmacokinetics, 20, 447-462.

Benton, D., Smoothy, R., \& Brain, P. F. (1985). Comparisons of the influence of morphine sulphate, morphine-3-glucuronide and tifluadom on social encounters in mice. Physiology \& Behavior, 35, 689-693.

Boissier, J. R., Grasset, S., \& Simon, P. (1968). Effect of some psy- chotropic drugs on mice from a spontaneously aggressive strain. Journal of Pharmacy \& Pharmacology, 20, 972-973.

Brain, P. F., Benton, D., Childs, G., \& Parmigiani, S. (1981). The effect of the opponent in tests of murine aggression. Behavioural Processes, 6, 319-328.

Brain, P. F., McAllister, K. H., \& Walmsley, S. (1989). Drug effects on social behavior: Methods in ethopharmacology. In A. A. Boulten, G. B. Baker, \& A. J. Greenshaw (Eds.), Neuromethods: Psychopharmacology (Vol. 13, pp. 687-739). Clifton, NJ: Humana.

Delini-Stula, A., \& Vassout, A. (1979). Differential effects of psychoactive drugs on aggressive responses in mice and rats. In M. Sandler (Ed.), Psychopharmacology of aggression (pp. 41-60). New York: Raven.

Delini-Stula, A., \& Vassout, A. (1981). The effects of antidepressants on aggressiveness induced by social deprivation in mice. Pharmacology, Biochemistry \& Behavior, 14(Suppl. 1), 33-41.

Eichelman, B. (1987). Neurochemical and psychopharmacologic aspects of aggressive behavior. In H. Y. Meltzer (Ed.), Psychopharmacology: The third generation of progress (pp. 697-704). New York: Raven.

ERIKSSON, E. (1987). Brain neurotransmission in panic disorder. Acta Psychiatrica Scandinavica, 76(Suppl. 335), 31-37.

Gex-Fabry, M., Balant-Gorgia, A. E., Balant, L. P., \& GarRONE, G. (1990). Clomipramine metabolism. Model-based analysis of variability factors from drug monitoring data. Clinical Pharmacokinetics, 19, 241-255.

Gianutsos, G., \& LaL, H. (1975). Aggression in mice after pchloroamphetamine. Research Communications in Chemical Pathology \& Pharmacology, 10, 379-382.

GolDBERG, M. E. (1970). Pharmacologic activity of a new class of agents which selectively inhibit aggressive behavior in rats. $A r$ chives Internationales de Pharmacodynamie et de Therapie, 186, 287-297.

IVERSEN, S. D. (1984). 5-HT and anxiety. Neuropharmacology, 23, 1553-1560.

KJELlberG, B., \& RandruP, A. (1975). Behavioural effects of thymoleptics in vervet monkeys (Cercopithecus aethiops). Psychopharmacologia, 43, 267-269.

KRSIAK, M. (1976). Effects of ethanol on aggression and timidity in mice. Psychopharmacology, 51, 75-80.

KRSIAK, M. (1979). Effects of drugs on behaviour of aggressive mice. British Journal of Pharmacology, 65, 525-533.

KrSIAK, M., \& Sulcova, A. (1990). Differential effects of six structurally related benzodiazepines on some ethological measures of timidity, aggression and locomotion in mice. Psychopharmacology, 101, 396-402.

Krsiak, M., Sulcova, A., Tomasikova, Z, Dlohozkova, N., Kosar, E., \& MASEK, K. (1981). Drug effects on attack, defense and escape in mice. Pharmacology, Biochemistry \& Behavior, 14, 47-52.

LeDouarec, J. C., \& Broussy, L. (1969). Dissociation of the aggressive behavior of mice produced by certain drugs. In S. Garattini \& E. B. Sigg (Eds.), Aggressive behavior. Amsterdam: Excerpta Medica Foundation.

Linnoila, M., Insel, T., Kilts, C., Potter, W. Z., \& MurPhy, D. L. (1982). Plasma steady-state concentrations of hydroxylated metabolites of clomipramine. Clinical Pharmacology \& Therapeutics, 32 , 208-211.

Maj, J., Mogilnicka, E., \& Kordecka, A. (1979). Chronic treatment with antidepressant drugs: Potentiation of apomorphine-induced aggressive behaviour in rats. Neuroscience Letters, 13, 337-341.

Martínez, M., Castaño, D., Simón, V., \& Brain, P. F. (1986). An ethopharmacological assessment of the influences of cyproterone acetate on social interactions in male mice. IRCS Medical Science, 14, 44-45.

MCTAvish, D., \& Benfteld, P. (1990). Clomipramine: An overview of its pharmacological properties and a review of its therapeutic use in obsessive compulsive disorder and panic disorder. Drugs, 39, 136-153.

MiCzeK, K. A. (1987). The psychopharmacology of aggression. In L. I. Iversen, S. D. Iversen, \& S. H. Snyder (Eds.), Handbook of psychopharmacology (pp. 183-327). New York: Plenum. 
Navarro, J. F., Miñarro, J., \& Simón, V. M. (1993). Antiaggressive and motor effects of haloperidol show different temporal patterns in the development of tolerance. Physiology \& Behavior, 53, 1055 1059.

Olivier, B., Mos, J., VAn der Heyden, J., \& Hartog, J. (1989). Setotonergic modulation of social interactions in isolated male mice. Psychopharmacology, 97, 154-156.

Redolat, R., Miñarro, J., Simón, V. M., \& Brain, P. F. (1991). Influences of haloperidol and sulpiride on social behaviour of female mice in interactions with anosmic males. Psicothema, 3, 79-85.

San Martin, R., \& Pardo, A. (1989). Psicoestadística: Contrastes paramétricos y no paramétricos. Madrid: Pirámide.

SCHMidT, W. J., \& MeIERL, G. (1980). Antidepressants and the control of predatory behavior. Physiology \& Behavior, 25, 17-19.

SHEARD, M. H. (1988). Clinical pharmacology of aggressive behavior. Clinical Neuropharmacology, 11, 483-492.

Shibata, S., Nakanishi, H., Watanabe, S., \& Ueki, O. (1984). Effects of chronic administration of antidepressants on mouse-killing behavior (muricide) in olfactory bulbectomized rats. Pharmacology, Biochemistry \& Behavior, 21, 225-230.

SMOOTHY, R., Brain, P. F., BERRY, M. S., \& HaUg, M. (1986). Alcohol and social behaviour in group-housed female mice. Physiology \& Behavior, 37, 689-694.

SoFIA, R. D. (1969). Effects of centrally active drugs on four models of experimentally induced aggression in rodents. Life Sciences, $\mathbf{8}$, 705-716.

Tiller, J. W. G. (1990). Antidepressants, alcohol and psychomotor performance. Acta Psychiatrica Scandinavica (Suppl. 360), 13-17.

Valdman, A. V., \& Poshivalov, V. P. (1986). Pharmaco-ethological analysis of antidepressant drug effects. Pharmacology, Biochemistry \& Behavior, 25, 515-519.
VAlZelli, L., \& Bernasconi, S. (1971). Differential activity of some psychotropic drugs as a function of emotional level in animals. Psychopharmacologia, 20, 91-96.

Valzelli, L., Giacalone, E., \& Garattini, S. (1967). Pharmacological control of aggressive behavior in mice. European Journal of Pharmacology, 2, 144-146.

Vergnes, M., Depaulis, A., \& Boehrer, A. (1986). Parachlorophenylalanine-induced serotonin depletion increases offensive but not defensive aggression in male rats. Physiology \& Behavior, 36, 653-658.

Vogel, G., Hartley, P., Neill, D., Hagler, M., \& Kors, D. (1988). Animal depression model by neonatal clomipramine: Reduction of shock induced aggression. Pharmacology, Biochemistry \& Behavior, 31, 103-106.

Vogel, G. W., MinTer, K., \& WoOLWINE, B. (1986). Effects of chronically administered antidepressant drugs on animal behavior. Physiology \& Behavior, 36, 659-666.

Willner, P., Theodorou, A., \& Montgomery, A. (1981). Subchronic treatment with the tricyclic antidepressant DMI increases isolation-induced fighting in rats. Pharmacology, Biochemistry \& Behavior, 14, 475-479.

WITTENBORN, J. R. (1978). Behavioral toxicity in normal humans as a model for assessing behavioral toxicity in patients. In M. A. Lipton, A. DiMascio, \& K. F. Killam (Eds.), Psychopharmacology: A generation of progress (pp. 791-801). New York: Raven.

YAмAмOTo, T., \& UeKı, S. (1978). Effects of drugs on hyperactivity and aggression induced by raphe lesions in rats. Pharmacology, Biochemistry \& Behavior, 9, 821-826.

(Manuscript received April 22, 1993; revision accepted for publication February 4,1994 .) 